\title{
Climatic Water Balance of Annapurna, Langtang and Khumbu regions of Nepal Himalaya
}

\author{
Tirtha Raj Adhikari and Lochan Prasad Devkota \\ Central Department of Hydrology and Meteorology, TU, Nepal
}

\begin{abstract}
For the protection of the environment, climatic water balance studies play key role. This study attempts to assess the potential water availability at the Annapurna, Langtang and Khumbu regions of Nepal Himalaya. Potential evapotranspitration (PET) is calculated by CROPWAT 8 with the help of maximum and minimum temperature, relative humidity, wind speed and sunshine hour. The climatic water balance of water bodies is calculated on the basis of Thornthwait procedure. These calculations help to examine annual water surplus (WS) and water deficit (WD) periods. Potential water surplus at three selected station is calculated by above techniques after averaging the data of time period from 1987 to 2008. The main aim of this study is to compare the obtained result from the climatic water balance for the selected sites of the Nepal Himalaya region. This study will provide climatic water balance information of the given area which will be useful for sustainable management of water resources in local and small area of the Nepal Himalaya.
\end{abstract}

Key words: Potential Evapotranspiration, Annual Water Surples, Annapurna, Langtang

\section{INTRODUCTION}

Snow and glacier are natural fresh water reservoir in solid form which is one of the important components of hydrological cycle in Nepalese Himalayas. Glacierized environments are one of the most vulnerable to climate change with regard to future availability of freshwater in the region (Mats et al., 2009). The perennial flow of major rivers in Nepal is maintained by melt water coming from these sources, which are vital for the water resources development of the country. Climatic water balance is one of the important factors while predicting glacier melt runoff (Barnett et al., 2005). Glaciers in Nepal are being hazardous due to the rising temperature trend, deposited carbon particles, decreasing winter precipitations and impact of global warming as a whole (Mats et al. ,2009). It may be vanished after few years because the glacier retreating rate was 10 to $60 \mathrm{~m}$ per year in Dudh Koshi basin (Bajracharya et al., 2008). In other countries as well such cases are being identified. For example, the park's largest glaciers in USA- Montana, is also retreating due to the effect of climate change (Hall and Fagre, 2003). This forecast was predicted by a computer-based climatological model as only computer based models are suitable for such scenario. The park's glaciers could disappear in the next several decades if the forecast appears to be true. The summer mean temperature in 2100 is predicted to reach $19.76^{\circ} \mathrm{C}$; however, glacier disappearance may occur even earlier, as many of the glaciers are retreating faster than their predicted rates (Hall and Fagre, 2003). 
This study attempts to calculate water deficit (WD) and water surplus (WS) by using Thornthwaite procedures and tries to identify the climatic water balance (CWB) in the study area. The result of CWB can be beneficial to understand the glaciers accumulation and ablation and its response with temperature, humidity, sunshine, wind speed and precipitation analysis. Seasonal cycle of precipitation, maximum, minimum and mean temperature analysis are also carried out as a part of analysis.

\section{STUDY AREA}

Department of Hydrology and Meteorology (DHM), Snow and Glacier Hydrological section was established in 1987 with an aim to monitor hydro-meteorological stations in the higher region (Northern belt) of Nepal. Now, DHM is operating eleven hydro-meteorological stations in different location of higher region of Nepal. But in this research three stations are selected as Annapurna (Latitude 28 $53^{\prime}$, Longitude 83⒐' in western part whose elevation is $3470 \mathrm{~m}$ a.m.s. 1, Langtang (Latitude 28 $22^{\prime}$ ', Longitude $85^{\circ} 62^{\prime}$ ') the elevation 3920m a.m.s.1. in Middle part and Khumbu (Latitude 27 $89^{\prime}$, Longitude $86^{\circ} 83^{\prime}$ ) the elevation $4355 \mathrm{~m}$ a.m.s.l. in eastern part of the country in Himalaya Region Nepal. The research stations are depicted in Figure 1.

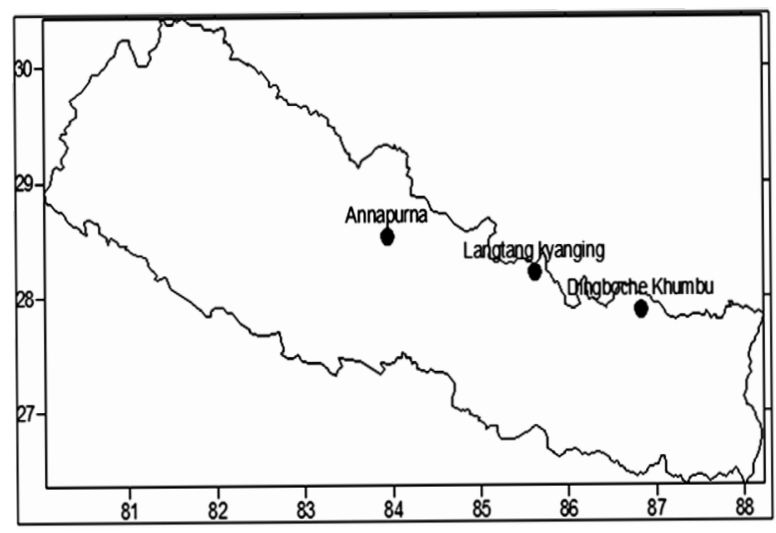

Figure 1: Study Area Meteorological Stations

\section{METHODOLOGY}

Climatic Water Balance is actual Precipitation (P) minus potential Evapotranspiration. Where, $\mathrm{P}$ is the hill shaded terrain based precipitation (Rainfall + Snow melting) data.

$\mathrm{CWB}=\mathrm{P}-\mathrm{PET}$

Several methods have been proposed in the literature for calculating actual evapotranspiration and Climatic Water Balance. Monteith (1963, 1965) introduced resistance terms into the well-known method of Penman (1948) and derived an equation for evapotranspiration from surfaces with either optimal or limited water supply. This method, often referred to as Penman-Monteith method, has been successfully used to estimate evapotranspiration from different land covers. The method requires data on aerodynamic resistance and surface resistance which are not readily available, so that the standard Penman-Monteith method for estimating actual evapotranspiration (AE) has been limited in practical used. For this practice CROPWAT 8.0 models is used for calculating the PET using different steps of the model. Several methods exist to determine AE. The FAO PenmanMonteith method has been recommended as the appropriate combination method to calculate PET and determine AE using the following:

- Maximum temperature

- Minimum temperature

- Humidity

- Sunshine duration

- Wind speed.

Daily maximum and minimum temperature, humidity, wind speed and precipitation (19872008) are collected from DHM, these data were averaged for three stations. The sunshine hour (1947 - 1990) was taken from the climate and hydrological Atlas of Nepal (ICIMOD, 1996). 
The sunshine hour and other climatological parameters are of not similar period but day length is similar in each and every year, therefore day length is considered in analysis. These data were used feed into the CROPWAT 8 model for calculating the potential evapotranspiration (PET), which uses Penman-Monteith method to estimate PET (ALLEN et.al, 1998). This method has also been applied in Xizhuang watershed (XZW) which lies in the middle mountains Baoshan region of southwest China with elevations ranging from 1695 to $3060 \mathrm{~m}$ by Ma Xing et al. (2008).

$\mathrm{PET}=\frac{0.408 \Delta(R n-G)+\gamma \frac{900}{T+270} u_{2}(e s-e a)}{\Delta+\gamma(1+0.34 u 2)}$

Where

PET $=$ Potential evapotranspiration $\left[\mathrm{mm} \mathrm{day}^{-1}\right]$,

$\mathrm{Rn}=$ Net radiation at the crop surface $\left[\mathrm{MJ} \mathrm{m}-2\right.$ day $\left.^{-1}\right]$,

$\mathrm{G}=$ Soil heat flux density $\left[\mathrm{MJ} \mathrm{m}^{-2}\right.$ day $\left.^{-1}\right]$,

$\mathrm{T}=$ Mean daily air temperature at $2 \mathrm{~m}$ height $\left[{ }^{\circ} \mathrm{C}\right]$,

$\mathrm{u}_{2}=$ Wind speed at $2 \mathrm{~m}$ height $\left[\mathrm{m} \mathrm{s}^{-1}\right]$,

es $=$ Saturation vapour pressure $[\mathrm{kPa}]$,

ea $=$ Actual vapour pressure $[\mathrm{kPa}]$,

$($ es-ea $)=$ Saturation vapour pressure deficit $[\mathrm{kPa}]$,

$\gamma=$ Psychometric constant $\left[\mathrm{kPa}^{\circ} \mathrm{C}^{-1]}\right.$,

$\Delta=$ Slope vapour pressure curve $\left[\mathrm{kPa}^{\circ} \mathrm{C}^{-1]}\right.$,

The equation uses standard climatological records of solar radiation (sunshine), air temperature, humidity and wind speed. Apart from the site location, the FAO PenmanMonteith equation requires air temperature, humidity, radiation and wind speed data for daily, weekly, ten-day or monthly calculations. Thronthwaite and Mather (1955) method has been used to calculate the climatic water balance. This method shows the relationship between rainfall, PET and actual evapotranspiration from which water surplus (WS) and water deficiency (WD) can be calculated at any place or region over a given period of time. The water balance accounting procedure with the subtraction of potential evapotranspiration (PET) forms the incoming precipitation (p) in each month. The negative value of (P-PET) indicates the amount by which $(\mathrm{P})$ failed to meet the water need. On the other hand Positive values of (P-PET) refers to amount that is in excess of the water need. Accumulated potential water loss (acc) is obtained by a progressively adding all the negative value of (P-PET). But if the soil has never reached the field capacity the first value of acc is obtained by a successive approximation method using the field capacity. The soil moisture decreases when $\mathrm{P}$ is lower than PET and increases when $\mathrm{P}$ is higher than PET. Change in soil storage (Cst) is obtained by subtracting the soil moisture in any month from that value in the previous month. When Precipitation is equal to or greater than PET, the actual evapotranspiration (AE) will be equal to PET. If $\mathrm{P}$ less than PET, AE is obtained by adding $\mathrm{P}$ to the magnitude of Cst. The difference of PET and AE gives the values of water deficiency (WD) as;

$\mathrm{WD}=$ PET-AE

Water surplus occurs only if the soil has been recharged to its field capacity and whenever precipitation is higher than PET and soil is not at the field capacity. The excess first goes to recharge the soil moisture. The water surplus (WS) can be written as

$\mathrm{WS}=(\mathrm{P}-\mathrm{PET})-\mathrm{Cst}$

The accuracy of the computation may be tested with the yearly of PET, P, AE, WD and WS in the following manner

$\mathrm{P}=\mathrm{AE}+\mathrm{WS}$

The connection with climatic water balance, the term water deficiency (WD) and water surplus (WS) are used. WD represents the amount of water loss through AE, which cannot be met 
by precipitation. In this article the seasons are classified as winter - December of the previous year to February (DJF), Pre-monsoon (spring) - March to May (MAM), Monsoon (summer) June to September (JJAS), Post-monsoon (fall) - October and November (ON). The seasonal effect of precipitation is strongly pronounced with high precipitation input during the monsoon (JJAS) and very little precipitation during $(\mathrm{ON})$ the winter period.

\section{MODEL AND DATA USED}

Monthly average data (1987 - 2008) of minimum temperature, maximum temperature, humidity, precipitation, wind speed and sunshine duration is used for calculating the PET. Similarly the CROPWAT 8.0 model is used for calculating the PET. Output from CROPWAT 8.0 PET, precipitation data is used for calculating AE, WS, WD. Water Surplus (WS) is the excess of water from precipitation fall after the soil water is replenished and the demand of PET is met. WD is a general term used to describe a situation where the available water within a region is less than the region's demand. It is the water that is available from precipitation (snow and rain) glacier melt for rivers and recharge of groundwater. The season wise (DJF, MAM, JJAS and $\mathrm{ON}$ ) water balance is calculated from the equation of temperature and precipitation at Annapurna, Langtang, and Khumbu. Moreover, the season wise climatic water balance is obtained from the Thronthwait climatic balance shown in Figure 5. For the field capacity $50 \mathrm{~mm}$ assumed, due to soil and evaporation routine parameters ranges $(50 \mathrm{~mm}-500 \mathrm{~mm})$ are used for the estimation of parameter uncertainty by Monte Carlo simulations (Seibert 1996). In the selected three stations there are not so much of missing data except in few cases. For the missing data in small (one day) gaps linear interpolation is adopted for temperature data and for the long gaps, monthly series are simply replaced by the mean values of the respective months. The data are then computed for annual as well as seasonal mean.

\section{RESULTS AND DISCUSSION}

\section{Precipitation}

Precipitation during the summer monsoon period which is a major component from accumulation of glacier in the Nepal Himalayas was strongly influenced by mesoscale mountain valley circulation. Remarkable diurnal variation was found in precipitation and had crucial effect on the distribution of precipitation. Especially, from October 1985 to March 1986, the amount of precipitation was large and it was controlled by behaviour of westerly trough (Western disturbances). Precipitation in the cold season is also associated with large scale snow cover. Due to the accumulation of glaciers in Nepal, it is important to determine the behaviour of the thermal circulation in mountain-valleyscale in the summer monsoon season and the behaviour of westerly trough in the remaining seasons. Especially, inter-annual variability of the latter is more important for the accumulation of glacier than was expected (Seko,1987). The snow line does not always coincide with the temperature $0^{\circ} \mathrm{C}$ isotherm throughout the year. The relation between snow line and air temperature are greatly changed from season to season (Morinage et.al., 1987). The fluctuation in snow line in Langtang valley was reported by Yamada et al. (1992) and Kappenberger et al (1993). Some studies related to mass balance of glaciers in the valley were evaluated by Ageta et al. (1984) and Steinegger et al (1993). Seko (1987), Seko and Takahshi (1991), Shiraiwa et al. (1992) and Ueno et al (1993) evaluate the distribution of precipitation in the valley. Although the altitudinal dependence of precipitation in the 
valley was evaluated largely by their analysis, it is still not enough to clarify how the local climate would change glacier area when the global climate impact. The precipitation up to $64 \%, 77 \%$ and $82 \%$ of long term annual total was observed at Annapurna, Langtang and Khumbu respectively during monsoon season (JJAS) in the Nepal Himalayan region which is depicted in Table 1.

From the three reference stations (Annapurna, Langtang and Khumbu) it can be started the total monthly average precipitation (1987 2008) varies over space. The average annual total precipitation at Annapurna, Langtang and Khumbu is $2304 \mathrm{~mm}, 653 \mathrm{~mm}$ and $405 \mathrm{~mm}$ respectively (Table 1).

\section{Temperature}

The mean monthly temperatures were calculated at Annapurna, Langtang and Khumbu which is presented at Table 2. The mean monthly maximum was observed to be $10.4^{\circ} \mathrm{C}$ at Annapurna, $9.9^{\circ} \mathrm{C}$ Langtang and $5.9^{\circ} \mathrm{C}$ in July. The average monthly minimum was observed to be $-1.3^{\circ} \mathrm{C}$ in Annapurna area in January, $-2.4^{\circ} \mathrm{C}$ in Langtang and $-6.0^{\circ} \mathrm{C}$ in
Table 1: Comparison, of seasonal cycle of Total Average precipitation (mm) (1987 - 2008)

\begin{tabular}{|c|c|c|c|}
\hline Month & Annapurna & Langtang & Khumbu \\
\hline Jan & 47 & 11 & 6 \\
\hline Feb & 83 & 18 & 7 \\
\hline Mar & 144 & 22 & 17 \\
\hline Apr & 197 & 31 & 8 \\
\hline May & 216 & 37 & 23 \\
\hline Jun & 313 & 87 & 43 \\
\hline Jul & 442 & 158 & 92 \\
\hline Aug & 463 & 168 & 133 \\
\hline Sep & 255 & 91 & 64 \\
\hline Oct & 99 & 23 & 7 \\
\hline Nov & 23 & 5 & 4 \\
\hline Dec & 23 & 3 & 2 \\
\hline DJF & 153 & 32 & 15 \\
\hline MAM & 556 & 90 & 48 \\
\hline JJAS & 1473 & 504 & 331 \\
\hline ON & 45 & 8 & 6 \\
\hline Total & $\mathbf{2 , 3 0 4}$ & $\mathbf{6 5 3}$ & $\mathbf{4 0 5}$ \\
\hline
\end{tabular}

Khumbu in February. This can be justified by the fact that the temperature decreases with altitude. The similar trends of air temperature variation are also found at all three stations. Freezing rain occurs when air temperature is above and ground surface is below $32^{\circ} \mathrm{F}$ $\left(0^{\circ} \mathrm{C}\right)$. If threshold temperature found to be up to the $-2^{0} \mathrm{C}$ temperature the precipitation will freeze (Seibert, 1996). From the temperature

Table 2: Maximum, minimum and mean temperature data which was used to derive PET using CROPWAT 8 model.

\begin{tabular}{|c|c|c|c|c|c|c|c|c|c|}
\hline & \multicolumn{9}{|c}{ Annapurna } \\
Month & Min T & Max T & Mean T & Min T & Max T & Mean T & Min T & Max T & Mean T \\
\hline Jan & -6.0 & 3.3 & -1.3 & -7.0 & 3.1 & -1.9 & -11.3 & 0.0 & -5.7 \\
\hline Feb & -5.9 & 3.7 & -1.1 & -7.2 & 2.4 & -2.4 & -11.4 & -0.6 & -6.0 \\
\hline Mar & -3.1 & 7.1 & 2.0 & -4.2 & 5.2 & 0.5 & -8.7 & 1.1 & -3.8 \\
\hline Apr & -0.5 & 10.5 & 5.0 & -1.3 & 8.0 & 3.4 & -5.7 & 3.5 & -1.1 \\
\hline May & 2.7 & 13.2 & 8.0 & 1.9 & 10.0 & 6.0 & -2.2 & 5.6 & 1.7 \\
\hline Jun & 5.6 & 14.0 & 9.8 & 5.2 & 11.4 & 8.3 & 1.7 & 7.7 & 4.7 \\
\hline Jul & 7.1 & 13.7 & 10.4 & 7.5 & 12.3 & 9.9 & 3.4 & 8.3 & 5.9 \\
\hline Aug & 6.9 & 13.5 & 10.2 & 6.9 & 11.9 & 9.4 & 3.1 & 7.9 & 5.5 \\
\hline Sep & 5.1 & 13.1 & 9.1 & 5.0 & 10.7 & 7.9 & 1.1 & 7.1 & 4.1 \\
\hline Oct & 0.9 & 11.8 & 6.4 & 0.5 & 8.5 & 4.5 & -4.2 & 4.9 & 0.4 \\
\hline Nov & -2.2 & 8.8 & 3.3 & -2.8 & 6.4 & 1.8 & -7.3 & 3.3 & -2.0 \\
\hline Dec & -3.6 & 6.4 & 1.4 & -4.8 & 5.2 & 0.2 & -8.7 & 2.6 & -3.0 \\
\hline Average & 0.6 & 9.9 & 5.3 & 0.0 & 7.9 & 3.9 & -4.2 & 4.3 & 0.1 \\
\hline
\end{tabular}


precipitation relationship as shown in Figure 6 of three Himalaya region stations, the percentage of freezing precipitation in Annapurna is $2 \%$, in Langtang is $4 \%$ and in Khumbu is $9 \%$. Above result shows that the freezing precipitation is lower than the melting rate, therefore glaciers are rapidly retreating in these regions. The glacier area loss is about $20 \%$ in last 40 years. The subsidence of glacier surface by $0.40 \mathrm{~m}$ per year in Dudh Koshi basin is also reported since late 1960's due to the melting of the glaciers. Bolch et al. (2008) and Bajracharya et al. (2008) have also reported the glacier retreat rate of 10 to $60 \mathrm{~m}$ per year in Dudh Koshi basin.

The mass balance of glacier can be divided into a winter and summer season, mainly influenced by freezing precipitation and mean threshold air temperature (Paterson, 1994). At the end of the summer, snow may be accumulating on the higher part of the glacier while ablation continues near the terminus. Thus the accumulation varies from place to place on the glacier (Paterson, 1994). The freezing precipitation is less where accumulation is also less. As Khumbu is in higher elevation as compared to two other stations, the average air temperature is found to be $-4.9^{\circ} \mathrm{C}$, which is lower than the threshold value, so there is more accumulation of snow in winter season shown in Table 3.

Percentage of Precipitation Freeze for accumulation in snow and glacier areas

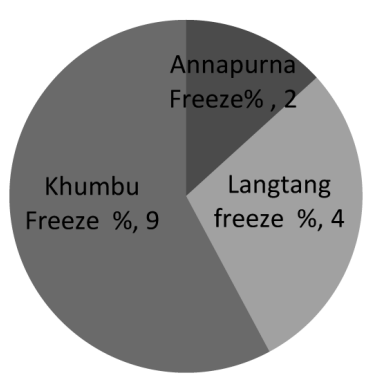

Figure 2: Percentage of freezing precipitation in glacier accumulation in three regions.
Table 3: Comparison of seasonal average temperature (1987-2008)

\begin{tabular}{|c|c|c|c|}
\hline Season & Annapurna & Langtang & Khumbu \\
\hline DJF & -0.4 & -1.4 & -4.9 \\
\hline MAM & 5 & 3.3 & -1 \\
\hline JJAS & 9.9 & 8.8 & 5 \\
\hline ON & 4.8 & 3.1 & -0.8 \\
\hline
\end{tabular}

\section{Potential Evapo-transpiration (PET)}

The PET is the amount of water that would be evaporated under an optimal set of conditions, among which is an ultimate supply of water. The highest value of PET was found in the month of May in all three stations as shown in Table 4. In Annapurna area, the PET shows quite variable trend in the modelled result (highest values of $96 \mathbf{~ m m}$ and the lowest value of $49 \mathrm{~mm}$ ). PET (Figure 4) was also decreased with elevation similar to the temperature shown in Figure 3.

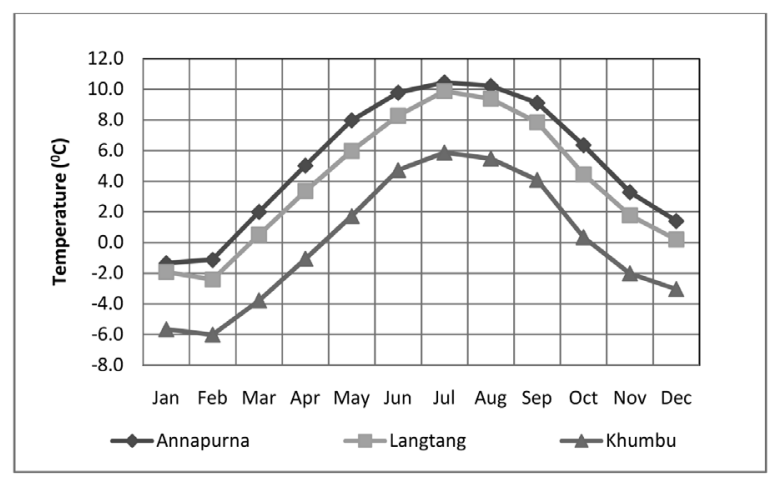

Figure 3: Comparison of Mean Temperature in three stations.

Table 4: Potential evapotranspiration in three stations (mm)

\begin{tabular}{|c|c|c|c|}
\hline Month & Annapurna & Langtang & Khumbu \\
\hline Jan & 49 & 53 & 50 \\
\hline Feb & 53 & 55 & 49 \\
\hline Mar & 68 & 70 & 59 \\
\hline Apr & 88 & 87 & 71 \\
\hline May & 96 & 92 & 73 \\
\hline
\end{tabular}




\begin{tabular}{|c|c|c|c|}
\hline Jun & 79 & 76 & 62 \\
\hline Jul & 76 & 76 & 63 \\
\hline Aug & 76 & 75 & 70 \\
\hline Sep & 71 & 68 & 57 \\
\hline Oct & 72 & 72 & 59 \\
\hline Nov & 63 & 62 & 60 \\
\hline Dec & 59 & 58 & 59 \\
\hline Total & $\mathbf{8 5 2}$ & $\mathbf{8 4 4}$ & $\mathbf{7 3 2}$ \\
\hline
\end{tabular}

\section{Actual evapotranspiration (AE)}

The $\mathbf{A E}$ is an output of water that is dependent on moisture availability, precipitation, sunshine hour, wind, temperature, and humidity. Think of $\mathbf{A E}$ as "water use" that is actually evaporating and transpiring. When the temperature increases, AE also increases as shown in Table 3 and Table 5. In this study $\mathbf{A E}$ is compared with temperature only. In Annapurna and Khumbu area PET $>$ AE in all season, but in Langtang area PET equals to $\mathbf{A E}$ in summer and in other season PET $>$ AE as shown in Table 5. This indicates that the deficit occurs when the soil is completely dried out. Actual evapotranspiration $\mathbf{A E}$ in a soil water budget is the actual amount of water delivered to the atmosphere by evaporation and transpiration. In wet months, when precipitation exceeds potential evapotranspiration, actual evapotranspiration is equal to PET. In dry months, when potential evapotranspiration exceeds precipitation, actual evapotranspiration is equal to precipitation plus the absolute value of the change in soil moisture storage.

Figure 4: Comparisons of potential Evapo transpiration in three stations

Table 5: Comparison PET, AE, WD and WS in three stations of Nepal Himalaya.

\begin{tabular}{|c|c|c|c|c|c|c|}
\hline Station Name & Parameter & Dec-Feb (DJF) & $\begin{array}{l}\text { Mar-May } \\
\text { (MAM) }\end{array}$ & $\begin{array}{c}\text { Jun-Sep } \\
\text { (JJAS) }\end{array}$ & $\begin{array}{c}\text { Oct-Nov } \\
(\mathrm{ON})\end{array}$ & $\begin{array}{l}\text { Total } \\
(\mathrm{mm})\end{array}$ \\
\hline \multirow[t]{4}{*}{ Annapurna } & PET & 161.0 & 252.0 & 303.0 & 136.0 & 852.0 \\
\hline & $\mathrm{AE}$ & 135.0 & 252.0 & 303.0 & 123.0 & 813.0 \\
\hline & WD & 27.0 & 0.0 & 0.0 & 13.0 & 40.0 \\
\hline & WS & 0.0 & 294.0 & 1170.0 & 27.0 & 1491.0 \\
\hline \multirow[t]{4}{*}{ Langtang } & PET & 166.0 & 249.0 & 295.0 & 134.0 & 844.0 \\
\hline & $\mathrm{AE}$ & 38.0 & 90.0 & 296.0 & 71.0 & 495.0 \\
\hline & WD & 129.0 & 159.0 & 0.0 & 63.0 & 351.0 \\
\hline & WS & 0.0 & 0.0 & 177.0 & 0.0 & 177.0 \\
\hline \multirow[t]{4}{*}{ Khumbu } & PET & 158.0 & 203.0 & 252.0 & 119.0 & 732.0 \\
\hline & $\mathrm{AE}$ & 20.0 & 49.0 & 232.0 & 55.0 & 356.0 \\
\hline & WD & 144.0 & 155.0 & 19.0 & 64.0 & 382.0 \\
\hline & WS & 0.0 & 0.0 & 49.0 & 0.0 & 49.0 \\
\hline
\end{tabular}




\section{Climatic Water Balance}

There is less water deficit $\mathbf{4 0} \mathbf{~ m m}$ at Annapurna than at other two stations (Langtang and Khumbu). The highest water deficit is $\mathbf{3 8 2} \mathbf{m m}$ at Khumbu and the lowest at Annapurna. Water deficit of $351 \mathrm{~mm}$ is found at Langtang as shown in Table 6 . Table 6 shows that the water deficit is increased from west to eastern Nepal Himalaya.

The highest water surplus of $1491 \mathbf{m m}$ was at Annapurna, $\mathbf{1 7 7} \mathbf{~ m m}$ at Langtang and the lowest $49 \mathrm{~mm}$ at Khumbu which is similar to the precipitation distribution, continuously increased from eastern to western Himalaya due to the altitudinal and monsoonal effect shown in Table 6.

\section{Table 6: Comparisons of climatic water balance} in three stations.

\begin{tabular}{|l|c|c|c|}
\hline $\begin{array}{c}\text { Climatology of water } \\
\text { Balance }\end{array}$ & Annapurna & Langtang & Khumbu \\
\hline Water Deficiency (mm) & 40.0 & 351.0 & 382.0 \\
\hline Water Surplus (mm) & 1491.0 & 177.0 & 49.0 \\
\hline
\end{tabular}

Devkota (2003) found the highest rainfall pocket of more than $320 \mathrm{~cm}$ annually over central mountainous region, particularly along the southern flanks of Anapurna range, whereas the driest part is found over the north of the same range with less than $40 \mathrm{~cm}$ annually. The strong rainfall gradient across this range shows the importance of topography on spatial variation of annual rainfall distribution in Nepal. The second highest rainfall zone of more than $240 \mathrm{~cm}$ per year is located over the northeast mountainous region. Tarai belt has rainfall distribution ranging from 160 to $200 \mathrm{~cm}$ annually, whereas the western Tarai shows less rainfall in comparison to the rest of the Tarai. While Devkota (2003) noted that highest rainfall zone is located at the middle mountainous region. The precipitation decreases with increase in altitude. The water surplus also shows similar trends as that of precipitation.

\section{CONCLUSION}

This study shows that the precipitation increases from eastern to western regions. It may be due to the orographic effect in the precipitation as three stations are located in the different elevations. PET is decreased with elevation similar to the temperature variation. The highest water surplus is found in the Annapurna areas, but less significant amount of water surplus is obtained in Langtang and Khumbu area Table 6. In Annapurna temperature and precipitation is higher than in comparison to the other two stations (Langtang and Khumbu). Therefore snow accumulation is higher and melting rate is also higher in Annapurna. Water surplus occurs in three seasons of the year (spring, summer and fall) at Annapurna station, but very small quantity of water surplus is found in Langtang and Khumbu in summer (Table 5). Water deficiency is increased from western to eastern regions whereas water surplus is increased from eastern to western regions. Freezing precipitation and climatic water balance shows that Annapurna area has the highest water surplus. This may be due to the fact that this area is located at the highest rainfall pocket of Nepal. The retreating rate is not similar in three catchments due to the difference in the temperature profile (Table 2) and the freezing precipitation (Figure 2). Snow melting rate is higher in the Annapurna area as the freezing precipitation is only $2 \%$. The melting rate of glaciers is higher in western region as compared to the middle and eastern regions of Nepal Himalaya.

\section{ACKNOWLEDGEMENTS}

The author would like to thank Department of Hydrology and Meteorology (DHM) for providing the necessary data for this research. 
Also, the author would like to acknowledge Dr. Sunil Kansakar for reviewing this paper and for his valuable feedbacks. Likewise, useful suggestions from Dr. Sunil Adhikary are highly acknowledged.

\section{REFERENCES}

Ageta, Y.,Iida, H and Watanabe, O. (1984): Glaciological studies on Yala Glacier in Langtang Himal. Glacial Studies in Langtang Valley, report of the Glacier Boring Project 1981-82 in the Nepal Himalaya, 41-47.

ALLEN, R.G., PEREIRA, L.S., RAES, D., SMITH, M., (1998), Crop evapotranspiration, guidelines for computing crop water requirements, FAO Irrigation and Drainage paper, no. 56, Rome, pp. 17.

Bajracharya, SR.; Mool, PK. \& Shrestha BR. (2008). 'Global climate change and melting of Himalayan glaciers.' In Ranade, PS; ed. Melting glaciers and rising sea levels: impacts and implications, Hyderabad, India, Icfai University Press, 28-46.

Barnett, T. P., Adam, J. C \& Lettenmaier, D. P. (2005) "Potential impacts of a warming climate on water availability in snowdominated regions" Vol 438/17 November 2005/doi:10.1038/nature04141.

Bolch, T.; Buchroithner, MF.; Peters, J.; Baessler, M. \& Bajracharya, S. (2008),Identification of glacier motion and potentially dangerous glacial lakes in the Mt. Everest region/Nepal using spaceborne imagery.' Nat. Hazards Earth Syst. Sci; 8, 1329-1340.

Devkota (2003), Climate variability over Nepal: observations, forecasting, model evaluation and impact on agriculture and water resources un published $\mathrm{PhD}$ thesis.

Hall, M. P. and D. B. Fagre. 2003. Modeled climateinduced glacier change in Glacier National Park, 1850-2100. Bioscience 53(2):131-140

ICIMOD (1996) climatic and hydrological atlas of Nepal, Kathmandu ICIMOD.
Journal agricultural water management 96(2009) 167 - 178, Elsevier science direct (homepage: www.elsevier.com/locate/agwat).

Kappenberger, G., Steinegger, U., Braun, L.N. and Kostka, R (1993): Recent changes in glacier tongues in the Langtang Khola basin, Nepal, determine by terrestrial photogrammetry. Snow and glacier hydrology, International Association of Hydrological sciences Publication, 218, 95-101.

Ma Xing, Xu Jianchu, and Qian Jie (2008), Water Resource Management in a Middle Mountain Watershed. A Case Study in Xizhuang, Yunnan, China.

Mats Eriksson, Xu Jianchu, Arun Bhakta Shrestha, Ramesh Ananda Vaidya, Santosh Nepal and Klas Sandstrom (2009), The changing Himalaya "Impact of climate change on water resource and livelihoods in the grater Himalayas" Published by ICIMOD.

Monteith, J.L., 1963. Gas exchange in plant communities. In: Environmental Control of Plant Growth.

Monteith, J.L., 1965. Evaporation and environment. Symp. Soc. Exp. Biol. 19, 205-234.Penman, H.L., 1948. Natural evaporation from open water, bare and grass. Proc. R. Soc. Lond., Ser. A 193, 120-145.Exp. Biol. 19, 205-234.

Morinage Yuki, Seko, Katsumoto, and Takahashi,Shuhei (1987), Seasonal variation of snow line in Langtang valley, Nepal Himalayas, 1985-1986, Bulletin of glacier research, 5 (1987) 49-53.

Paterson W.S.B. (1994), The Physics of glaciers $3^{\text {rd }}$ Edition, Elsevier Science Ltd

Seibert Jan (1996) Estimation of Parameter Uncertainty in the HBV Model Paper presented at the Nordic Hydrological Conference (Akureyri, Iceland - August 1996).

Seko,K and Takahashi, S (1991), Characteristicss effect oof winter precipitation and it glacier in the Nepal Himalaya. Bulletin of Glacier Research 9, 9-16. 
Steinegger, U., Braun, L.N, Kappenberger, G.,and Tortari G (1993): Assessment of annual snow accumulation over the past 10 years at high elevation in the Langtang region. Snow and glacier hydrology, International Association of Hydrological sciences Publication, 218, 155-165.

Thornthwaite, C.W. and Mather, J.R. (1955), The water balance. In publication of climatology, Vol.8 No.1:1-86.

Ueno, K. ,Shiraiwa, T and Yamada, T. (1993); Precipitation environment in the Langtang
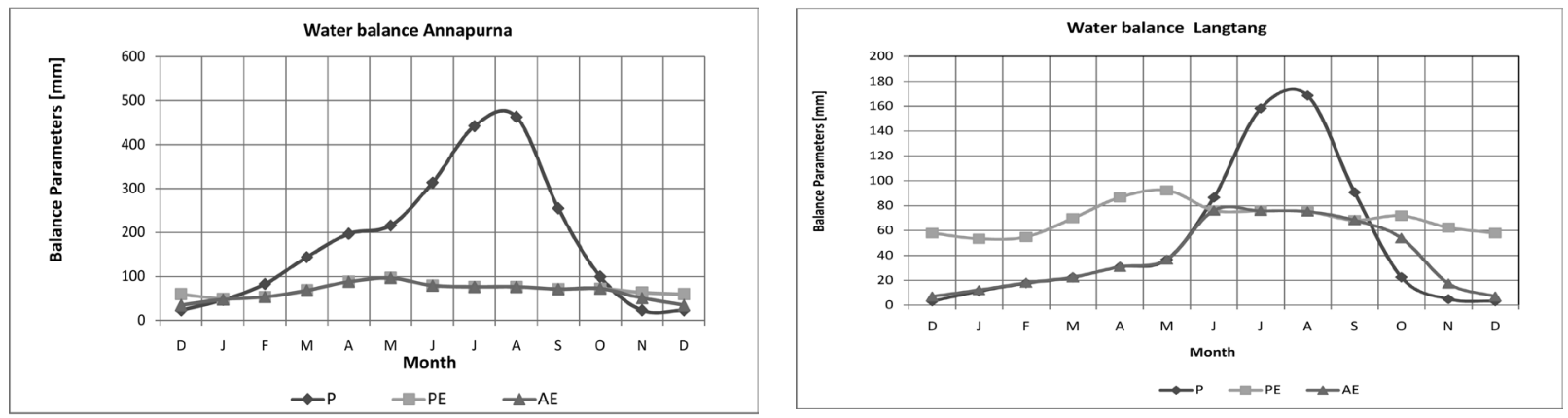

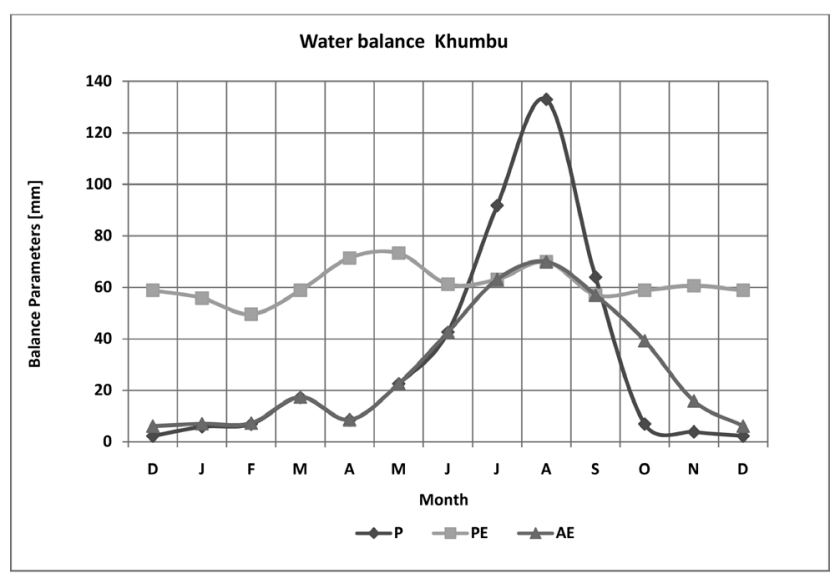

Figure 5: Climatic water balance of Annapurna, Langtang and Khumbu. 


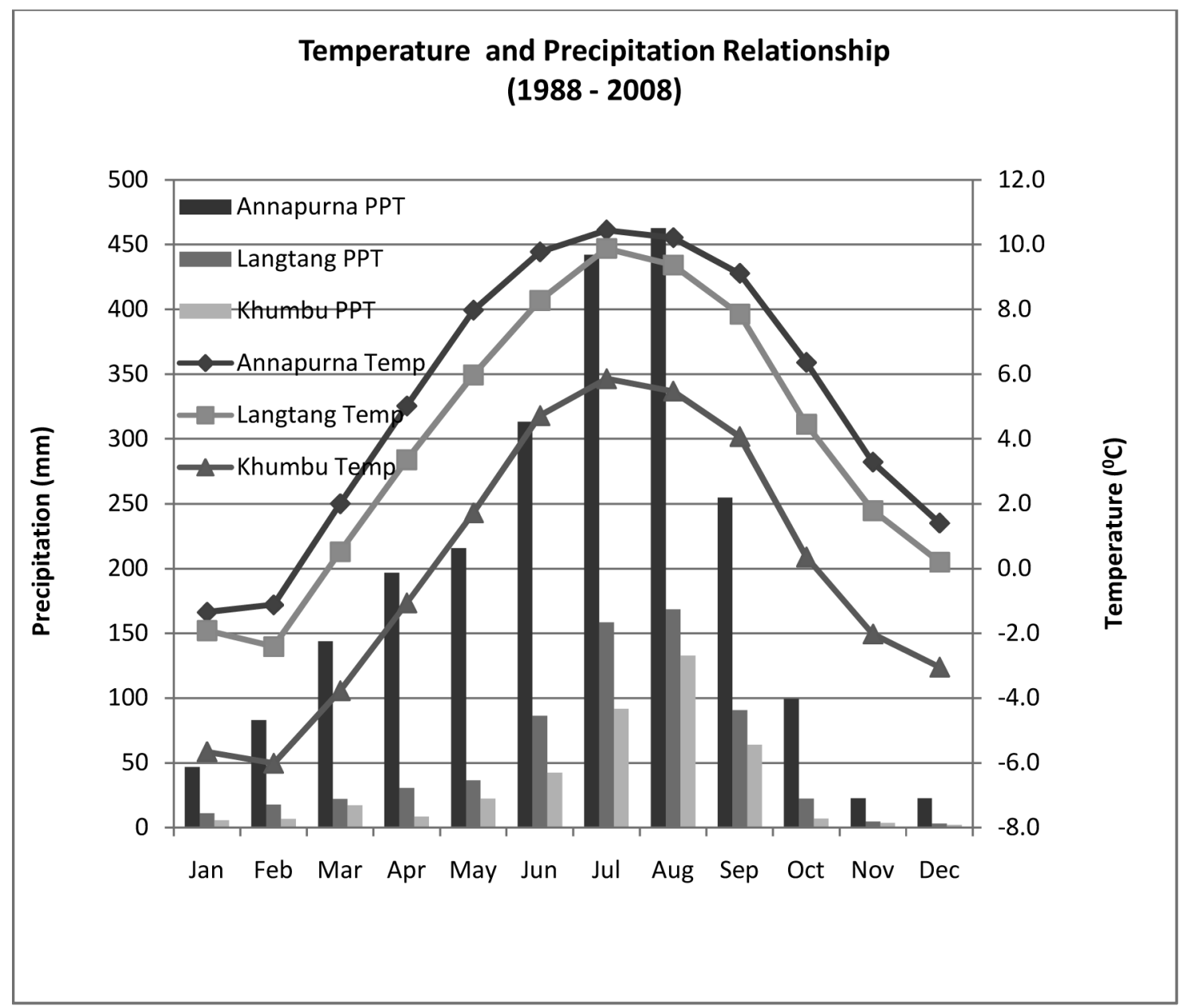

Figure 6: Temperature and precipitation of Annapurna, Langtang and Khumbu. 